\section{SARCOMA OF THE TONGUE}

\section{A STUDY OF THE PUBLISHED CASES WITH REPORTS OF TWO NEW CASES}

\section{W. T. COUGHLIN, B.S., M.D.}

Fellow of the American College of Surgeons; Assistant Professor of Surgery, St. Louis University School of Medicine

ST. LOUIS

A diagnosis of sarcoma in any part of the body seems always to fill the mind of the attending surgeon with a certain foreboding of ill in the prognosis. Rightly or wrongly, there persists for a time at least in the minds of those near the patient the haunting fear that there is far more likelihood of recurrence, or of metastasis, than probability of complete and permanent cure after the first surgical intervention.

The cases here reported aroused an interest, and a study of the condition was undertaken to find out the known and published facts concerning sarcoma of the tongue. The reader will not be wearied with airy spectulation, and scant space will be given to any theoretical opinion, no matter how eminent its source.

Search through the literature (English, French and German) has brought to my notice fifty-eight reported cases. From a study of these and the two of my own, the following opinions were formulated.

Of course, one is aware that reports of not all the cases are published. The same is true of sarcomas elsewhere as of other conditions. However, one will conclude that at the present day the disease that can boast of only fifty-eight reported cases must be rare. Most of the cases have been recorded since 1885 . Butlin at that time wrote of sarcoma of the tongte, "It would be quite useless to try to write an account of it which shall be useful."

The best article 1 have found on the subject is that of Fripp and Swan ${ }^{1}$ herein frequently referred to.

\section{FTIOLOGY}

Age.-It is the commenly accepted opinion that all varieties of sarcoma are more common in children. I think this is the ustial medical school teaching. I.et us see whether it be true with regard to sarcoma of the tongue.

The disease may be prenatal in onset - the congenital type. There are three such cases on record, those of Jacobi, ${ }^{2}$ Naegele ${ }^{3}$ and Delbanco ; ${ }^{4}$ that is to say 4.9 per cent. of all reported cases were congenital.

Of the postnatal type the earliest was one appearing in a 7-weeks-old child. ${ }^{5}$ The next earliest was in a child of 10 months, ${ }^{6}$ and this completes the number of cases of the acquired type found in children under 1 year, 3.2 per cent.

Two more cases, one at 2 and the other at 4 years, make a total of four seen in the first decade, that is, 7.8 per cent. of the acquired type. No cases whatever were reported between the ages of 4 and 14, and all of those occurring in the second decade were seen between the ages of 14 and 19 . Three cases at 17, two at 19 and one at 14 make up the total, six cases, between 10 and 20 years, or 11.7 per cent. Adding together those in the first two decades, we find ten

1. Fripp and Swan: Guy's Hosp. Rep., 1902, p. 88

2. Jacobi: Am. Jour. Obst., 1869, ii, 81.

3. Naegele: Inaug. Dissert., Kiel, 1900 A (Foote).

4. Delbanco: München. med. Wchnschr., 1898, xlv, 155

5. Gross: Philadelphia Med. Times, 1872 , p. 272

6. Targett: Guy's Hosp. Rep., 1890, p. 24. cases showing up in patients under 20 years, 19.6 per cent. of all.

I believe that this ought to convince one that the disease is not more common in the early years of life.

After adult life is reached the condition is more frequent. Thus in the twenties there are ten reported cases, 19.6 per cent., or just exactly as many as are found in the first two decades put together. The oldest of these was 28 and the youngest 22 years of age.

In the fourth decade the maximum of frequency is attained - fourteen cases, or 27.4 per cent. of all acquired cases, were found in the thirties.

Between 40 and 50 are only six, 11.7 per cent., and in the sixties only four are recorded, 7.8 per cent., and the oldest of these was 65 . The oldest patient of all was 71 , and this was the only one found in the eighth decalle.

In seven of the cases recorded no mention was made of the age. These were thrown out and the foregoing percentages calculated on a total of fifty-three cases of the acquired type.

Sex-On looking over the cases one is impressed with the preponderance of males - thirty-three cases. The number of females is twenty. In seven of the cases no mention of the sex was made. The relative known proportion of males to females is $33: 20$, or 62.2: 37.7 per cent. One cannot conclude that it is more common in either sex at any particular period of life, the foregoing relations being fairly well maintained in all the decades.

Nationality.-In only seven cases was mention made of the nationality of the patient. Five of these were Europeans and the other two (my cases) were American born, the one of Irish and the other of Italian descent.

Occupation.-This was stated in ten cases, one was a pupil in a grammar school and one in high school Two were medical students, one was a teacher, and the remainder were of the laboring class. One should not be surprised to find most of the cases coming from among the laboring class, nor should one hastily conclude that the disease must be more common in labor ing persons. There are probably more persons in this than in any other class, and the percentage of cases may not be higher.

Precious Injury--In only ten of the cases was any mention made of previous injury. In four the tongue had been bitten some time previously, ranging from eight months ${ }^{2}$ to eight years (author's Case 2 ). Another had a broken tooth, which irritated the side of the tongue, and heavy cigaret smoking was supposed to have increased the irritation. ${ }^{\$}$ In one a cyst had been removed five years before and the tumor grew in the scar.) In one the tongue had been scalded two years previously. ${ }^{10}$ In one a beard of wheat penetrating twenty-two years, ${ }^{11}$ and in one a fish-bone entering two months before ${ }^{12}$ may have been etiologic factors. It is possible then that previous injury may play a part in the etiology in at least 16 per cent. of the cases of sarcoma of the tongue.

\section{PATHOLOGY}

Site.- The location of the growth is stated with fair accuracy in forty cases. In fifteen cases it was said to

\footnotetext{
7. Dunham: Am. Jour. Med. Sc., 1895, cx, 259.

8. Bleything: New York Med. Jour., 1883, p. 683

9. Murray: Ann. Surg., 1895, xxii, 271.

10. Littlewood: Lancet, London, 1898, i, 507.

11. Serafini: Rev de chir, $1909, \times 1,242$.

12. Downie: Brit. Med. Jour., 1899, ii, 1065
} 
have been located at the tip or within half an inch therefrom. In only three ${ }^{13}$ of these was there at first involvement of the under surface, and one is said to have involved the whole thickness of the anterior third. ${ }^{14}$ Of these fifteen cases, six were on the right and only one on the left, while the temaining eight were about the middle of the tip. The total number found involving the base of the tongue was nineteen. Five cases were said to have been on the right and two on the left side of the base. In five cases "the right half" and in three "the left half" was said to have been involved.

Altogether then, sarcoma of the tongue seems to have been more common on the right side and toward the basc, although no one part of the tongue can be said to be an especially favorite site of the growth.

The sarcoma begins most often in the tongue substance and grows toward the dorsum, soon causing a projection on the upper surface. In one instance, however, in which it sprang from the root or the base of the tongue above the hyoid bone, it grew downward and forward, causing a bulging beneath the chin. ${ }^{15}$ Here, as elsewhere, it is the rule for sarcoma to infiltrate the muscles lying in its neighborhood, growing between the fibers, which are soon destroyed. It soon traverses the median septum and invades the other side of the tongue. It spreads to the faucial pillars and to the floor of the mouth, and when either or both of these become involved the organ becomes fixed, thus rendering the patient unable to protrucle the tongue, and increasing the difficulty of swallowing. ${ }^{16}$

The rate of growth varies greatly. One case was said to have been growing twenty-two years. ${ }^{11}$ It had, however, begun to grow rapidly a short time before operation. In by far the greater number of cases the patient came for relief in less than ten months after the appearatice of the growth, in one within six weeks. ${ }^{17}$

Pedicle.-The tumor has been provided with a pedicle or stalk in six instances. ${ }^{18}$ In one of these a growth could be traced through the pedicle into the tongue, ${ }^{1:}$ and in another ${ }^{12}$ there was recurrence, so that in these two at least there can be no doubt as to the correctness of the diagnosis; the others are cloubtful.

Size.- The size of the tumor is mentioned quite frequently and varies within wide limits. The smallest was only "the size of a large pea." 20 Another was "as large as an orange," while one weighed $400 \mathrm{gm}^{21}$ and the others varied between these limits. The smallest was of the round-cell type while the largest was a "fascicular sarcoma" (spindle-cell sarcoma?). Many

\footnotetext{
13. These are reported by the following:

Targett: Guy's Hosp. Rep., 1890, p. 24 . Mandillon: Mém. et bull. Soc. de méd. de Borde
Swan).

Poncet: Rev. de chir., 1897 (Fripp and Swan).

14. Mickulicz and Michelson: Atlas der Krankh. des Mundes w. Rach. Berlin, 1892, No. 2, Plates 35 and 37.

15. Schulten: Deutsch. Ztschr. f. Chir., xxxv, 417

16. Beregszaiszy: Krankheiten der Zunge, Vienna, Butlin, 1887, p. 226. Murray: Ann. Surg., 1895, xxii, 271. Butlin, Knight: Lancet, London, March 26, 1887 , p. 623 .

17. Lichtwitz: Arin. internat. de laryng., 1898 (Fripp and Swan)

18. The six instances are as follows:

Nelchoir, Robert: Rev. de chir., 1899, xvii, 546.

Mickulicz and Michelson: Atlas der Krankh. des Mundes u. Rach. Berlin, 1892, No. 2, Plates 35 and 37.

Mercier: Rev. med. de la Suisse Rom., 1890 (Fripp and Swan).

Marion: Rev. de chir., 1897 (Fripp and Swan).

Iichtwitz: Arch. internat. de laryngoi., 1898 (Fripp and Swan).

Downie: Brit. Med. Jour., 1899, ii, 1065.

19. Marion: Rev. de chir., 1897 (Fripp and Swan).

20. Mandillon: Mém. et bull. Soc. de méd. de Bordeaux, 1888 (Fripp and Swan).

21. Poncet: Rev. de chir., 1897 (Fripp and Swan).
}

were said to have been "walnut-sized," "the size of a hen's egg," etc., while some were diffuse and the size not stated.

Surface.-The color of the mucous membrane covering the tumor as a rule does not vary much from normal. There may be dilated veins over the surface ${ }^{22}$ or the mucous membrane may be very thin or there may be abrasions or excoriations which bleed easily when touched. In both my cases the mucosa over the summit of the tumor was paler than normal, as though stretched over an avascular body, while in Foote's case the color was darker than normal. Hutchinson noted that those growing up from the dorsum behind the circumvallate papillae were likely to present a papillary surface. Generally, the mucous membrane covering the tumor is smooth, and when the tumor presents on the dorsum of the tongue. the mucosa is always firmly fixed to the growth. When, however, the sarcoma first appears on the under surface of the tongue, it is not unusual to find the mucosa freely movable over it, and in two cases it was paler than normal.

Ulccration of the surface is commonly seen, the more so of course in advanced cases or large growths. It does not often occur on the under surface, and when it does it is usually because the growth presses on the teeth. Foote noted ulceration on the side of the tumor where it pressed on the teeth. Altogether, note was made as to presence or absence of ulceration twentynine times. In eleven of these ulceration had occurred. The time at which ulceration occurs varies within wide limits. The case of Serafini referred to above had been growing twenty-two years: it was said, however, to have rapidly increased in size a short time before operation, and it was ulcerated. No statement is made as to the time at which ulceration first appeared in anv of them. One har existed only two months, and was already ulcerated. ${ }^{23}$ Seven of those ulcerated were round-cell, three of them were spindle-cell and one was a mixed-cell sarcoma. In one the tumor completely sloughed out, ${ }^{24}$ so that "nothing remained to justify the diagnosis of sarcoma." It appeared later in the glands, however.

Glandular Inrolicment.-In view of the fact that sarcomas found in regions rich in lymphoid tissue often spread through the lymph-stream, and remembering the presence of lympioid tissue in the tongue, it is important to know the frequency of glandular metastasis in sarcoma of the tongue. Altogether, the question as to gland involvement was answered thirtyseven times. In the others no mention of glands is made. In eighteen of the thirty-seven the glands were enlarged; just what glands we are not told, but presumably the regional glands.

In four of these cases no glandular enlargement was noticed until after operation, and the question arises in the reader's mind as to whether this enlargement was not simple inflammatory hyperplasia following absorption from the operation wound in the mouth. The subsequent history proves, however, that in two of them there was glandular metastasis; the third $r \in$ mains doubtful, while in the fourth the enlargement subsided spontaneously and was most likely not sarcomatous.

Of those enlarged before operation, fourteen in number, one is of doubtful character, inasmuch as the

22. Shambaugh: Am. Jour. Med. Sc., 1902, cxxiii, 115.

23. Beregszaiszy: Krankheiten der Zunge, Vienna, Butlin, 1887, p. 226 24. Keenan: Ann. Surg., 1904, xxxix, 956. 
glandular enlargement had existed fifteen years, while the tongue condition had been present only three years. This patient was also designated scrofulous. ${ }^{25}$

There are, therefore, thirteen with glandular involvement before operation, and two in which the glands were found to be involved after operation, a total of fifteen cases out of thirty-seven with undoubted glandular metastasis, or 40.5 per cent.

As to the time at which glandular involvement first appeared we have not sufficient data. In one instance the tumor was said to have been present in the tongue less than two months before the glands became involved. ${ }^{1}$

As to the kind of cell in the parent tumor with glandular metastasis, it is hard to make general deductions from the evidence at hand. In thirteen cases mention was made of the type of cell: of these, seven were round-cell, 53.8 per cent.; four were spindle-cell, 38.4 per cent., and two were of the mixed-cell type, 7.7 per cent.

It will be seen farther on that altogether there were twenty cases of round-cell sarcoma reported, and in these the regional lymphatic glands were involved seven times. Dare one say that round-cell sarcoma of the tongue spreads by way of the lymphatics in seven cases out of twenty - in 35 per cent. of the cases? We shall see also that there were in all sixteen cases of spindle-cell sarcoma. Four of these, or 25 per cent., metastasized by the lymph route. And of the mixed-cell type (round and spindle), there were six cases, two of which showed glandular involvement $33 \mathrm{I} / 3$ per cent.

Cut Section.-The color on cut section varies. In both of mine on cut section the middle of the tumor was whitish and more pink-tinged toward the periphery. "Pinkish gray" is an expression often used to describe the color on section, but some have been red. The color varies with the vascularity of the growth. The spindle-cell growths are as a rule firmer and less vascular than the round-cell type. Pigmentation has not been noticed.

The growth may be firm (my Case 2) or fluctuant, ${ }^{12}$ or its consistency may vary anywhere between these two extremes. One finds that both round-cell and spindle-cell growths have been fluctuant, and that tumors of both types have been punctured, ${ }^{26}$ or incised $^{12}$ (mistaken for abscess or cyst?), so that the type of cell present cannot have much influence on the consistency of the tumor. On puncture or incision no fluid other than blood has escaped. Serious bleeding from the growth has occurred; in fact, one patient bled to death ${ }^{27}$ from a recurrent round-cell sarcoma.

Correctly to classify the reported cases is, I am sure, quite impossible. The descriptions are in the main incomplete and the nomenclature used often conveys (to me) little idea of the histologic picture. Such expressions as "medullary cancer" and "plexiform sarcoma" may be quite right, but I do not understand them. In two instances the diagnosis is simply "sarcoma."

Abbe $^{28}$ reported a case of angiosarcoma, as did also Santesson. ${ }^{25}$ Matrissimone's ${ }^{29}$ case was a myxosarcoma, while Godlee's ${ }^{30}$ case was a sarcoma of the gland

25. Santesson: Virchow-Hirschi. Jahresb., i, 280.
26. Butlin, Knight: Lancet, London, March 26, 1887, p. 623.

26. Butlin, Knight: Lancet, London, March 26, 1887, p. 623.

27. Hutchinson: Tr. Med.-Chir. Soc.

29. Matrissimone, abstracted by Pagenstecher: Centralbl. f. Chir., 1904, p. 604 .

30. Godlee: Lancet, London, March, 1887, p. 524 . of Nuhn and Blandin and called an adenosarcoma. Murray's ${ }^{9}$ was an endothelioma. These I leave unclassified, not knowing whether to place them with sarcomas or not. The term "lymphosarcoma" is used frequently enough; believing that by so doing I simplify matters, I have classed all such with the roundcell sarcomas.

There were forty-tline cases in which the type of cell was noted. Of these twenty-two were round-cell. In only six of them, however, was reference made to the size of the cell, and these were of the small-cell variety. In forty-nine cases therefore of sarcoma of the tongue, 44.8 per cent. were round-cell.

The spindle-cell type was not so often encountered, there being only nineteen cases altogether, or 38.7 per cent

There were eight cases in which both round and spindle cells were found-- mixed-cell 16.3 per cent. In one of these in addition cartilage cells were present (my Case 1), and in the case of Godlee ${ }^{30}$ referred to above, but not included in this class, was found "a calcifying nodule as large as a pisiform bone."

The growth is said to have been encapsulated or partly encapsulated in five of the cases. One of these was the case of Abbe, an angiosarcoma (?). Eve's ${ }^{31}$ case was a mixed-cell sarcoma. A case of Butlin's ${ }^{32}$ (Knight, Mr.) recorded as having a capsule was circumscribed but not encapsulated and consisted of small round cells. Downie's ${ }^{12}$ case was a spindle-cell sarcoma, and as well as being encapsulated was pedunculated; that of Wiggin was a spindle-cell sarcoma, which had been growing in the posterior part of the tongue for seven years. It recurred in the scar very soon after operation, so there is no doubt as to the diagnosis.

Symptoms.-Usually the first symptom noticed by the patient is the feeling as though a foreign body were in or on the tongue, ${ }^{24}$ and depending on whether the growth is in the anterior or posterior part of the tongue, the next is likely to be interference with speech or deglutition. ${ }^{33}$ In two instances the patient first sought relief for "sore throat." 34

Bleeding on mastication was the first sign in the cases of Marion ${ }^{19}$ and Mickulicz. ${ }^{14}$ These were both pedunculaterl growths. Bleeding may occur independently of mastication and may be very severe; in fact, in one case this was the cause of death. ${ }^{27}$ Bleeding may occur without ulceration. ${ }^{22}$

Pain or soreness has been observed very often, pain more often. This is usually in the tongue at the site of growth and may occur only at intervals as in my cases. It may occur in the presence or absence of ulceration. In the absence of ulceration it may occur at intervals and be of a sharp, stabbing character. Soreness does not often occur without ulceration, but when this happens both soreness and pain may become constant. The pain may radiate to the ear of the same side. $^{35}$

It may occur only on attempting to protrude the tongue or on taking food. It is sometimes so severe as entirely to prevent chewing or the swallowing of

31. Eve: Tr. Path. Soc. London, 1886, p. 223.

32. Butlin: Diseases of the Tongue, 1885, p. 259.

33. Albert: Wien. med. Presse, 1885, p. 171. Shambaugh: Am. Jour. Med. Sc., 1902, cxxiii, 15. Fripp and Swan: Guy's Hosp. Rep., 1902 p. 88 .

34. Downie: Brit. Med. Jour., 1899, ii, 1065. Scheier: Berl. klin. Wclischr., 1892, p. 584 .

35. Murray: Ann. Surg., 1895, xxii, 271. Scheier: Berl. Jlin. Wchnschr., 1892 , p. 584 . 
solids. $^{36}$ It has been known to disappear as the tumor grew larger. ${ }^{24}$ A tickling and burning sensation accompanied the pain in the throat in the case of Schleinzer. ${ }^{37}$

Difficult swallowing is a constant symptom when the tumor is in the base of the tongue, but it has also been noted when the growth was anteriorly situated. ${ }^{38}$ The dysphagia is not always due to the pain, but the tumor may mechanically interfere with swallowing. This has been seen in growths beginning in the base or root of the tongue, ${ }^{39}$ and in those involving the fauces or pharyngeal wall. ${ }^{40}$ It was the first symptom in the case of Fripp and Swan. ${ }^{1}$

An accumtilation of mucus in the back of the throat was an early sign in Shambaugh's case. ${ }^{22}$ An increased expectoration was noted in the case of Schleinzer. ${ }^{37}$ When for any reason swallowing is difficult or painful, drooling of saliva occurs. ${ }^{35}$

Dyspnea is common as a late symptom. It is most often found in those cases in which the tumor is situated far back in the tongue, but in Poncet's case the growth began in the under surface of the tongue; this, however, was a large tumor. A small growth in the tongue just in front of the epiglottis can early interfere with respiration. ${ }^{22}$ In the case of Wiggin the patient was obliged to sleep sitting because of pharyngeal obstruction on each attempt at lying down.

Fetor $\mathcal{c}$. ore has been noted twice. ${ }^{41}$ In both cases ulceration was present. It will be found more marked in those who do not take trouble to keep the mouth and teeth clean.

Inability to close the mouth properly is seen in the case of large tumors. ${ }^{* 1}$ In the case reported by Perkins the tumor during the past six months was said to have caused a habitual recurrent dislocation of both jaws on attempts at opening the mouth.

Protrusion of the tongue may be interfered with or totally prevented. This occurs when the growth, spreading through the root of the tongue, involves the floor of the mouth or the fauces and pharyngeal wall.".

A blister on the tongue where it had been bitten was the first sign in Dunham's case. ${ }^{7}$ It persisted for three or four months and then grew hard and tumor-like.

In many of the cases loss of weight and anemia have been remarked. They have been present in cases without as in those with ulceration of the tumor, but I find that all so affected suffered with dysphagia.

Diagnosis.-The condition is a rare one and there is no macroscopic picture on which one may depend. Failure to make a diagnosis, however, will usually be due to failure to remember that there is such a thing as sarcoma of the tongue. It may be confused with inflammatory lesion or with other new growths. Of the inflammations, chronic interstitial glossitis, tuberculosis, lues, actinomycosis or chronic abscess are the most likely to lead to error.

Tuberculosis is generally seen as an ulcer at the side or tip on the dorsum of the tongue, but it may begin as a small lump or tumor, and if so might lead to the diagnosis of sarcoma. It is as a rule found only in

36. Beregszaiszy: Krankheiten der Zunge, Vienna, Butlin, 1887, p. 226. Fisk: Ann. Surg., 1903, xxxvii, 273.

37. Schleinzer: Deutsch. Ztschr. f. Chir., 1911, cix, 283.

38. Perkins: Ann. Surg., 1896, xxiii, 585.

39. Albert: Wien. med. Presse, 1885, p. 171. Schulten: Deutsch. Ztschr. f. Chir., $\times x \times v, 417$

40. Scheier: Berl. klin. Wchnschr., 1892, p. 584.

41. Scheier: Berl. klin. Wchnschr., 1892, p. 584. Schleinzer: Deutsch. Ztschr. f. Chir., 1911, cix, 283.

42. Beregszaiszy: Krankheiten der Zunge, Vienna, Butlin, 1887, p. 226. Murray: Ann. Surg., 1895, xxii, 271. those who have well-advanced tuberculosis of the lungs. It ulcerates early. The ulcer shows some tendency in places to heal or granulate, and this a sarcomatous ulcer ordinarily does not do. Still, a case is referred to above in which the whole sarcoma sloughed out, and "left nothing to justify the diagnosis of sarcoma.".24

The luetic lesions likely to be mistaken for sarcoma are the chancre, the gumma and the diffuse infiltration. The chancre's ulcerated surface, generally raised up on an infiltrated base, reaches its maximum size in a couple of weeks, and ceases to grow. The ulcer precedes the tumor. The glandular enlargement occurs early and is usually very marked. Pain is not common nor is soreness. The appearance of secondary symptoms within six weeks is the rule.

A gumma grows rapidly. It is usually near the middle line and pain is absent. A yellowish or grayish spot soon appears in its center; it breaks and discharges a thick mucoid matter. The resulting ulcer is "punched out" or has undermined edges and its floor is covered with a grayish or yellowish membrane. It soon shows signs of healing.

Diffuse infiltration of lues sometimes attacks the tongue. It usualiy begins in the deeper parts of the tongue and early impairs the movement of the tongue. There is no tumor to be found and the tongue is only slightly increased in size. Pain is not common or severe and ulceration of the surface does not often occur. If the conditions have existed for long the surface of the tongue is bosselated, and painful fissures may develop in the sulci.

Actinomvcosis usually presents signs of inflammation from the beginning: abscess formation with resulting sinus is the rule. Then ensues the diffuse and spreading infiltration with further sinus formation. Later, the granules are seen and the microscope makes the diagnosis easy.

With chronic abscess of the tongue I have had no experience, nor do I find more than a reference to it in the records consulted. Aspiration might be used to clear up the diagnosis.

The condition will hardly be mistaken for benign new growth. It is of far more serious import to the jatient to mistake a benign growth for a sarcoma.

Benign growths develop slowly and rarely cause pain. Their outline is usually more clearly defined and they seldom, unless by their size, interfere with the mobility of the tongue. In some of the cases of sarcoma there is a history of the presence of a tumor for many years, but it is to be noticed that shortly previous to consultation the tumor had begun to grow rapidly. A papilloma may appear on the side or tip of the tongue and soon cause the patient to seek relief. Such a growth can be readily removed together with a small portion of the tongue substance, and then a microscopic examination of its point of attachment will reveal its true nature. The sarcomas infiltrate.

Macroglossia is present at birth. The tongue protrudes. Its whole anterior part is enlarged, and it seems edematous though it is often hard. The papillae are hypertrophied. Its rate of growth is slow.

Glandular cysts develop at the tip, along the sides and on the under surface. They may be of slow or rapid growth. They often alternately enlarge and diminish in size. Usually they are grayish and semitranslucent, as their content is most often retained inspissated mucus, which escapes on puncture. 
The diagnosis of thyroglossal tumor has been made in a case of sarcoma. ${ }^{43}$ The cyst or tumor growing from the remains of a thyroglossal duct is to be found in the median line and in the base of the tongue. It is painless and grows slowly, and until large interferes only slightly with tongue movement. Such tumors are to be removed when found, and at operation the discovery that the tumor is encapsulated will probably lead the surgeon to make a correct diagnosis before mutilation has been done.

Sarcoma of the tongue is not likely to be mistaken for a carcinoma, but if this should occur, the error is not a serious onc, as the treatment is the same in either case. In the case of sarcoma a tumor appears which later ulcerates, while in carcinoma the ulcer, as a rule, is first noticed. A painful chronic indurated ulcer appearing at some point of irritation points to carcinoma; but it is well to remember that at least one sarcoma first appeared as an ulcerated spot in the scat of a scald. ${ }^{10}$ In both we are likely to meet glandular enlargement, but this is more common in carcinoma.

After all clinical manifestations have been duly weighed, a diagnosis should not be made until one has excluded syphilis by both Wassermann test and antisyphilitic treatment. This causes a delay of from ten days to three weeks, but the benefits overbalance the dangers.

It used to be said that suspicious growths should be carcfinlly watched. It should be urged that suspicious grow ths be promptly removed.

All efforts to make a diagnosis may fail until a section of the tumor is examined under the microscope. It is necessary to obtain the section from the edge of the growth that one may, if possible, see both sound and diseased tissue in the section. One must bear in mind that the removal of a section may lead to rapid fungation in the growth, as happened in the case of Barling. ${ }^{44}$ Therefore no section should be removed until one is ready to do immediately whatever is indicated by the report of a competent pathologist.

Treatment and Prognosis.--The treatment has been operative in forty-six of the certain cases. In four no operation was done. In two no history is available. the specimens having been found in the museum of the Royal College of Surgeons.

Local removal only has been primarily done in twenty-five cases. two of these with division of the jaw (one of which lived four years without recurrence); three were removed with a $V$-shaped piece of the tongue (one of these was free from recurrence six years after, one two and one-half years after and one has been lost sight of).

Ten of the local excisions are noted as having recurred. In six others less than two years have elapsed since operation. Only three of the twenty-five patients are know'n to be well more than two years. Of the others there is no postoperative history.

The more radical operative treatment comprises $(a)$ removal of one-half the tongue and $(b)$ total removal of tongue and some adjacent part or parts.

There were twelve grouped in Class A. Of these, one had lived fourteen years, ${ }^{12}$ one five years, and one three and one-inalf years without recurrence. Three others had lived less than one year without recurrence, to wit, two, nine and eleven months, respectively.

43. Wiggin: Am. Jour. Med. Sc., 1906, xlvii, 24

44. Barling: Brit. Med. Jour., 1897, i, 297.
There were eleven cases in which removal of the tongue or more was done. Of these, four are free from recurrence after two and one-half, three. four and five years, respectively. One was well one year after operation. One was lost sight of, and three recurred in a year or less.

In the great majority of cases, the knife was used for the removal of the growth. In two instances it was followed by the actual cautery. One of these recurred in eight days; the other patient remained well two and one-half years afterward.

The electrocautery was used three times in excising the grouvth; one patient was well two years later, one well two weeks after and the other died soon of recurrence.

Coley's fluid was used before operation by Foote ${ }^{45}$ without apparent benefit. It is still being used in my second case. Trypsin and holadin were used in Wiggin's case ${ }^{43}$ and with seeming benefit for a while. Pyoktanin was also used in the case of Foote, but it seemed to make the condition worse.

The Roentgen ray was used after operation by Fisk, ${ }^{46}$ but with what effect we are not told. It, too, is still being used in my second case. For the difficult respiration, tracheotomy may become necessary (Fripp and Swan). ${ }^{1}$ The palliative treatment must be symptomatic.

In formulating my ideas of the prognosis I consider only the fifty cases in which the microscopic examination was made.

It may be conceded that left to itself, sarcoma of the tongue is a uniformly fatal disease. The length of time required by the disease to run its course when uninfuenced by treatment will be very difficult to foretell. In one case ${ }^{23}$ death occurred about two months after the first appearance of the tumor. Naegele's patient died of pneumonia in a little more than three months. ${ }^{3}$ In the other untreated cases recorded the patient was lost sight of or no mention is made of the final outcome.

Fripp and Swan, ${ }^{1}$ in personal communication with the surgeons who had reported cases, were able to follow twenty-five cases in which operation had becn performed. Eleven of the patients had lived without recurrence from six months to thirteen years. In thirteen of them there had been recurrence. Three of these "recurred in a short time" and four had remained well more than two years. In one of these four, recurrence appeared three, and in another three and onehalf years after operation. In nine cases the recurrence was local only, and in one in the regional glands alone, while in four recurrence appeared both in situ and in the glands. These thirteen patients died of the recurrence.

Of patients with the round-cell type, only four out of thirteen remained well longer than three years. Of the spindle-cell variety only two out of twelve were free from recurrence after two years. One of these patients had been operated on four and the other eight years previously. Downie ${ }^{47}$ informs me that in his case--spindle cell-the patient is well after fourteen years.

One expects the prognosis to be better after a primary operation than after an operation for recurrence, but one finds that this is not necessarily so. Schlein-

45. Foote: Am. Jour. Med. Sc., 1912, i, 198

46. Fisk: Ann. Surg., 1903, xxxvii, 273

47. Downie: Personal communication to the author. 
$z e r^{37}$ reported one well five years after an operation for recurrence in situ and in the glands, and this in a round-cell sarcoma ("lymphosarcoma"!).

As to metastasis through the blood-stream, there are three cases in which this seems to have occurred. ${ }^{48}$ In one of these, ${ }^{23}$ the whole course of the disease was only two months and in another eleven. Murray's patient died in three years of metastasis in the brain. In the case of Beregszaiszy, ${ }^{23}$ the peritoneum, mesentery and bowel wall were the seat of metastatic growths; in Keenan's ${ }^{21}$ the stomach and peritoneum; while the skin was the site of metastasic deposit in a case of Butlin's. ${ }^{32}$

'The direct cause of death may be exhaustion, pneumonia, sepsis or hemorrhage. I find no death occurring during the operation or immediately afterward. It is likely that a death attributed to sepsis, or pneumonia, or hemorrhage, occurring within eight days may be laid to the operation; one does not say so positively.

Recurrence has been noted up to three and a half years after operation. ${ }^{49}$ I find no recurrence to have been delayed longer than this. Recurrence has been seen as early as eight days after operation, ${ }^{40}$ and several recurred in two weeks.

The probability of recurrence after local excision is impossible to estimate from the case reports. Of eleven undergoing the intermediate operation (half the tongue with or without glands) four had been previously operated on by local excision, and in the nine requiring the most radical treatment only two were secondary operations.

There are certain cases reported in which the tumor was said to have been present for from six to twentytwo years. ${ }^{50}$ In several of these the statement is made that the tumor had shortly before operation taken on rapid growth.

A fibroma that takes years for its development may show nearly the same microscopic picture as a spindlecell sarcoma. ${ }^{51}$

\section{CASE REPORTS}

Case 1.-A. H., schoolboy, aged 14, Irish-American, comes because of lump growing in tip of tongue. Lump has been growing five or six months. History of having bitten tongue about two years ago. Has occasional darting pains in tongue and cannot speak as he used to. Has not lost weight, is well nourished and strong.

There is an irregularly oval lump in the tongue at its tip, slightly more on the right side than on the left. The lump is about $3 / 4$ inch long and about $1 / 2$ inch wide at its middle; it projects both on the dorsal and under surfaces. It is whitish below and pinkish above. The papillae can be seen on the posterior but not on the anterior part of its upper surface. There is no ulceration. The mucous membrane above is fixed to the growth; that below is fixed to it anteriorly only. It is firm to the feel, resilient and irregular. One projecting boss in the lower anterior part is hard. No fluctuation. No glands feelable.

48. Beregszaiszy: Krankheiten der Zunge, Vienna, Butlin, 1887, p. 48. Beregszaiszy: Krankheiten der Zunge, Vienna, Butlin, 1887, p.
226. Keenan: Ann. Surg., 1904, xxxix, 956. Murray: Ann. Surg., 1895, xxii, 271.

1895, xxii, 271.

49. Fripp and Swan.' Soc London, $1869, \mathrm{xx}, 157$ Hutchinson: Tr. 50. Heath: Tr, Path. Soc. London, 1869, xx, 157. Hutchinson: Tr.
Med.-Chir. Soc. London, 1885, p. 311. Abbe: Ann. Surg., 1894, xx, 72.

Perkins: Ann Sturg. 1896, xxiii, 595. Abbe: Ann. Surg, 1894, xx,

51. In addition to the references already given, the following will be found of interest:

Cheatle: Med. Press and Circular, 1906, ii, 14.

Fiedler: Ztschr. f. Med., Chir. u. Geburtsh., 1864, new series, iii, 305.

Huter: Berl. klin. Wchnschr., 1869, xxxii, 346.

Michael: Handb. d. Laryngol. u. Rhinol., 1899, ii, 634

McBurney: Med. Rec., New York, 1893, xliii, 439 .

Stern: Deutsch. med. Wchnschr., 1892, p. 495.
The diagnosis hung between new growth and implantation cyst and it was decided to remove it.

Under local anesthesia (novocain 0.5 per cent. infiltration in tongue on each side well back from tumor) a $\mathrm{V}$-shaped portion of the tongue bearing the tumor was excised. The base of the part removed measured $1 \mathrm{I} / 2$ inches and from middle of base to apex measured $13 / 8$ inches. Through-andthrough interrupted silkworm-gut stitches about $1 \mathrm{~cm}$. apart had been placed before the incisions were made and these when tightened controlled the bleeding and closed the wound.

There was very little shock.

Liquid diet was allowed and talking forbidden.

Union was by first intention and the last stitch was removed on the ninth day.

Cut in two, the tumor was solid throughout with a sharply limited edge. In its anterior part was a nodule about $1 \mathrm{~cm}$. in diameter which was semitranslucent, somewhat opalescent, and harder than the adjacent tissue. The scraped surface yielded a whitish mucoid substance.

The specimen was sent for microscopic examination and the report came back that the growth appeared to be sarcomatous and contained round and spindle cells and that a part of it contained cartilage cells.

The patient returned no more after the stitches were removed and inquiry showed that a false address had been given. Nothing further has been heard of him by me.

CASE 2.-L. D., 19, male, Italian-American, student. Lump in tongue, began to grow two and one-half or three months ago; has a drawing feeling and occasional sticking pain not very severe. Bit the tongue eight years ago at site of growth. Growth has always been hard. Had not interfered with movement of the tongue, nor with speech up to three weeks ago. It was then removed but is now growing again. The patient now has a slight lisp. Sections were made from growth removed and a diagnosis of sarcoma was made. A glance at the slides (brought along) showed an infiltrating growth made up of spindle and round cells, the former predominating.

The growth in tongue is situated $3 / 4$ inch back from the tip and is just to the left of the median line. It is pinkish and the surface is raised rounded above the level of the dorsum about $\mathrm{T} / 4$ inch and on its summit is a small puckered scar; the growth is about the size of an ordinary marble. It is fixed in the substance of the tongue, is regular of surface, spherical in form and has a resilient feel. There is slight tenderness. This the patient attributes to the recent operation. There is nothing in the history to arouse suspicion of syphilis, and the Wassermann is negative.

The growth was removed in August, 1913. The cheek was split as far as the masseter on the affected side. The root of the tongue was transfixed and a silver wire carried through and tied (twisting) as far behind the foramen cecum as possible. (I do not think this wire did any good whatever; it was recommended as a preventive of bleeding.) The rest of the technic followed Whitehead's procedure for the removal of half the tongue except that one had to go well to the right of the median line and the lateral incision was directed obliquely backward as I believed by so doing I should secure a better approximation, and I did. There was bleeding from the right lingual (ranine), but the left was caught before being cut. Not more than an ounce or two of blood was lost altogether. Not so much would have been lost but that it was deemed advisable to remove a little more from the right side opposite where the growth had been, necessitating a third cut. When the silkworm-gut stiches were drawn tight all the bleeding was well controlled. Healing was by first intention.

Microscopic examinations showed an infiltrating growth composed of round (small) and spindle cells.

The use of Coley's fluid was begun in the first week and is still continued. Massive dosage of the Roentgen ray was advised and the patient still receives one treatment per month. He writes me that he speaks with a lisp only when he gets excited. He has recently gained 11 pounds in weight and says he feels perfectly well. 